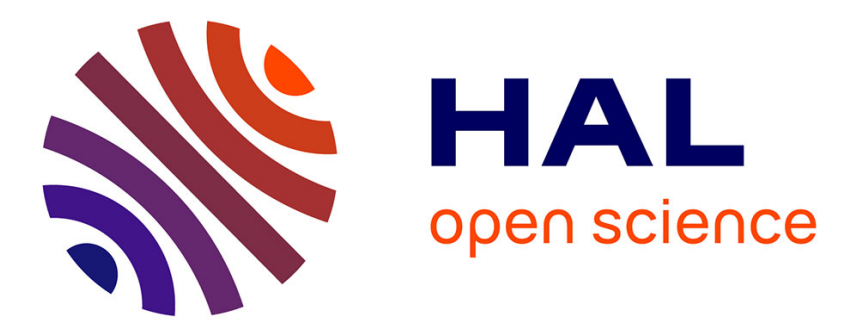

\title{
Effects of acute ozone stress on reproductive traits of tomato, fruit yield and fruit composition
}

\author{
Aye Aye Thwe, Gilles Vercambre, Hélène Gautier, Frédéric Gay, Jessada \\ Phattaralerphong, Poonpipope Kasemsap
}

\section{To cite this version:}

Aye Aye Thwe, Gilles Vercambre, Hélène Gautier, Frédéric Gay, Jessada Phattaralerphong, et al.. Effects of acute ozone stress on reproductive traits of tomato, fruit yield and fruit composition. Journal of the Science of Food and Agriculture, 2015, 95 (3), pp.614-620. 10.1002/jsfa.6798 . hal-01026158v2

\section{HAL Id: hal-01026158 \\ https://hal.science/hal-01026158v2}

Submitted on 17 Feb 2017

HAL is a multi-disciplinary open access archive for the deposit and dissemination of scientific research documents, whether they are published or not. The documents may come from teaching and research institutions in France or abroad, or from public or private research centers.
L'archive ouverte pluridisciplinaire HAL, est destinée au dépôt et à la diffusion de documents scientifiques de niveau recherche, publiés ou non, émanant des établissements d'enseignement et de recherche français ou étrangers, des laboratoires publics ou privés.

\section{다(1)(2)}

Distributed under a Creative Commons Attribution - ShareAlikel 4.0 International 


\title{
Effects of acute ozone stress on reproductive traits of tomato, fruit yield and fruit composition
}

\author{
Aye Aye Thwe, ${ }^{\mathrm{a}, \mathrm{e}^{*}}$ Gilles Vercambre, ${ }^{\mathrm{b}}$ Hélène Gautier, ${ }^{\mathrm{b}}$ Frédéric Gay, ${ }^{\mathrm{c}}$ Jessada \\ Phattaralerphong ${ }^{\mathrm{d}}$ and Poonpipope Kasemsap ${ }^{\mathrm{e}^{*}}$
}

\begin{abstract}
BACKGROUND: Tomato is sensitive to ozone. Fruit growth and composition are altered under ozone stress by modification of reproductive development. Fifty-one-day-old plants were exposed to three concentrations of $0 z 0 n e\left(200,350\right.$ and $\left.500 \mu \mathrm{g} \mathrm{m}^{-3}\right)$ for $4 \mathrm{~h}$.

RESULTS: Ozone reduced well-developed fruit number and fruit size, but it did not significantly affect flowering rate and fruit setting rate. The effect of ozone depends on organ developmental stage at the time of ozone application, as flowers and young fruits at the time of ozone exposure were more affected. Contents of total soluble sugars (total SS), total organic acids (total OA) and ascorbic acid (AsA) increased in fruits harvested from ozone-treated plants. Tomato fruit composition was altered under ozone stress, leading to a lower sugar:acid ratio. These changes were mostly due to increased contents of malic acid, ascorbate and glucose despite a decrease in sucrose.
\end{abstract}

CONCLUSION: Acute ozone exposure up to $500 \mu \mathrm{g} \mathrm{m}^{-3}$ greatly influences tomato fruit quality. As final fruit yield was not significantly reduced, it highlighted that there may be compensatory mechanisms present in the reproductive structures of tomato. Further research would be necessary to determine how reproductive traits are affected by repeated ozone exposure or longer-term exposure.

(c) 2014 Society of Chemical Industry

Keywords: ozone; yield components; fruit quality; sugars; acids; ascorbate; sugar:acid ratio; tomato

\section{INTRODUCTION}

Tropospheric ozone has been increasing and it has become one of the most dangerous oxidant molecules for plants. It damages human health and natural ecosystems, and reduces crop yields. ${ }^{1}$ Ozone mainly enters the leaf via the stomata and reacts with cell walls and membranes, causing membrane disruption, subsequent cell death with chlorotic flecking, necrosis and bronzing of foliage. ${ }^{2}$ Consequently, ozone impact on physiological processes may result from direct injury to leaves, triggering impaired photosynthesis and/or indirect effect due to variation in the carbohydrate allocation pattern, reducing non-photosynthetic organ growth. ${ }^{3}$

Fewer studies have been dedicated to the impact of ozone on plant reproductive traits. Leisner and Ainsworth ${ }^{4}$ reviewed the damaging impacts of current levels of ozone on reproductive development and yield of several agricultural crops from 128 peer-reviewed articles. They reported that current ambient ozone concentrations significantly decreased seed number $(-16 \%)$, fruit number $(-9 \%)$ and fruit weight $(-22 \%)$. Fruit growth and composition vary depending on growing conditions and may be affected by other environmental stresses. Many different stages of reproductive development are sensitive to ozone. ${ }^{5}$ It was shown that on fruiting plants of strawberry exposed to ozone $\left(184 \mu \mathrm{g} \mathrm{m}^{-3}\right.$ ozone for 69 days) inflorescence production was initially accelerated, followed by a reduction in inflorescence production rate and fruit setting rate. ${ }^{6}$ In addition, ozone treatment $\left(156 \mu \mathrm{g} \mathrm{m}^{-3}\right.$ ozone for 2 months exposure) caused a decrease in ascorbic acid content, a higher lipid peroxidation and lowered the sweetness of strawberry fruit due to modification of the carbohydrate pool in the fruit. ${ }^{7}$ These studies indicated that ozone alters fruit yield and quality by modifying the development of reproductive organs. As the demand for fruit quality has increased among consumers

\footnotetext{
* Correspondence to: Aye Aye Thwe, Department of Horticulture, Yezin Agricultural University, 05282 Nay Pyi Taw, Myanmar. E-mail: ayethwe. phyo07@gmail.com; Poonpipope Kasemsap, Department of Horticulture, Tropical Agriculture, Kasetsart University, 10900 Bangkok, Thailand. E-mail: agrppk@ku.ac.th

a Department of Horticulture, Yezin Agricultural University, 05282 Nay Pyi Taw, Myanmar

b INRA, UR 1115, Plantes et Systèmes de culture Horticoles, Domaine St Paul, Site Agroparc, F-84914 Avignon, France

C CIRAD, UMR111 Eco\&Sols, F-34060 Montpellier, France

d Faculty of Natural Resources and Agro-Industry, Kasetsart University Chalermphrakiat Sakon Nakhon Province Campus, 47000 Thailand

e Department of Horticulture, Tropical Agriculture, Kasetsart University, 10900 Bangkok, Thailand
} 
looking for tastier, healthier and safer products, the role of air pollutants such as ozone on crop yield and fruit quality needs to be considered as a special issue.

Among horticultural crops, tomato stands as an important economic crop around the world, the consumption of which provides low calories with high contents of vitamins, minerals and other secondary compounds. Tomato fruit quality may be characterized by external (size, colour, firmness) and internal (flavour, aroma and texture) traits. It is stated that concentration of sugar and acid determines the gustative quality of tomato fruits; so that increasing fruit quality is associated with increased content of sugars and organic acids in tomato. ${ }^{8,9}$ The quality varies with cultivar, ${ }^{10-12}$ ripeness stage ${ }^{13}$ and environmental conditions during crop/fruit growth and development. ${ }^{14-17}$

Crop yield and quality are determined by endogenous growth capacity of plants, which depends on genetics and the environmental conditions. Consequently, both direct and indirect impacts of ozone exposure could affect different processes in plants, leading to differences in crop yield and quality. Many studies have been conducted on plant growth, crop yield and quality in response to ozone. However, these impacts depend on crop growth stages. ${ }^{18}$ Therefore, in this experiment, ozone was applied at the reproductive stage in order to determine whether an abiotic stress such as an ozone exposure will affect the growth and development of organs and their storage capacity. The objective of this study was to evaluate the impact of an acute ozone stress on tomato reproductive traits, with a special focus on fruit yield and quality.

\section{MATERIALS AND METHODS}

\section{Growth conditions and management practices}

Tomato seeds (Solanum lycopersicum Mill. Var 'Look Tor', indeterminate type) were sown directly in $12.6 \mathrm{~L}$ glass pots. The soil, containing $30 \%$ sand, $22 \%$ silt and $48 \%$ clay, was mixed with cow dung and burned rice husk at a ratio of 2:1:1 by volume. The seeds were sown at the rate of three seeds per pot and the strongest plantlet was selected from them after germination. The glass pots were arranged in a randomized complete block design with five replications. The plants were grown in a white net house ( $3 \mathrm{~m}$ height) throughout the experiment (Kasetsart University, Thailand). The pots were arranged at a distance of $90 \mathrm{~cm}$ from centre to centre between the rows and $60 \mathrm{~cm}$ within the rows. The experimental duration was from November 2010 to February 2011. Throughout the growth of the plant, fertilizer applications were done four times: a basal application (at the time of soil mixing), and three times as side dressing according to fertilizer recommendations. ${ }^{19}$ Plant protection practices were applied to the plants as needed. Malathion 8 flowable (Gowan) (malathion 79.5\%) at a rate of 1.7-2.3 $\mathrm{Lha}^{-1}$ and mancozeb (zinc-manganese ethylene, bisdithiocarbomate $75 \%$ ) at a rate of $1.6-2.2 \mathrm{~kg} \mathrm{ha}^{-1}$ were used alternately. Furadan $5 \mathrm{G}(5 \%(\mathrm{w} / \mathrm{w})$ carbofuran) was used while the soil was mixed. Watering was done manually each day until drainage.

\section{Ozone exposure}

Two plastic closed top chambers $(120 \mathrm{~cm} \times 120 \mathrm{~cm} \times 200 \mathrm{~cm})-$ one growth chamber for treatments and one growth chamber for control - were constructed for ozone fumigation. The plastic chambers were constructed outside the net house. The plants from the net house were moved to the plastic chambers at the time of ozone exposure and were transferred back to the original place after treatment. When the plants were 51 days old (1147 degree days, $\left.{ }^{\circ} \mathrm{Cd}\right)$, three concentrations of ozone (200, 350 and $500 \mu \mathrm{g} \mathrm{m}^{-3}$ ) were applied. At the time of ozone exposure, the fourth truss was flowering and the second truss had begun setting fruit. Ozone application was given for half a day (from 7:30 a.m. to $11: 30$ a.m.). In each ozone exposure, two to three plants were placed into each plastic chamber and thus three ozone treatments were completed in 6 days $\left(1147-1250^{\circ} \mathrm{Cd}\right)$. Ozone was applied using an ozone generator (Model OZ 8010, Ozonic International Co., Ltd, Thailand) and the concentration of ozone inside the chamber was measured by a computerized ozone analyser (Model 49i, Thermo Fisher Scientific Inc., US EPA) throughout the fumigation period. For the control chamber, the ambient air was allowed to pass the cooling pad throughout the fumigation period. The ozone level inside the control chamber was less than $20 \mu \mathrm{g} \mathrm{m}^{-3}$. Temperature and relative humidity inside and outside the chamber were measured throughout. Temperature inside and outside the chamber was around 31.7 and $30.5^{\circ} \mathrm{C}$ and relative humidity was $66 \%$ and $67 \%$ during ozone exposure.

\section{Reproductive traits}

The number of flowers per truss, number of fruits per truss and truss number were recorded throughout the experiment (every 3 days). For each truss, the fruit-setting ratio was calculated as the percentage of fruit number to the total number of flowers. Flower and fruit development were calculated in relation to degree days accumulated from the seeding date using the base temperature of $8{ }^{\circ} \mathrm{C} .^{20}$

\section{Fruit sampling and chemical analysis}

Fruit harvesting for chemical analysis started when the plants were about 70 days old. Fruits were harvested at turning ripeness stage and their length, width and weight were measured. Developed fruit number was calculated considering every fruit weighing more than $15 \mathrm{~g}$. Single fruit weighing less than $15 \mathrm{~g}$ were classified as not well developed. Fruits were washed thoroughly with water and cut on ice into four pieces and the jelly, including the seeds, was removed. Two opposite sides of each fruit were kept, weighed and stored in a deep freezer $\left(-80^{\circ} \mathrm{C}\right)$ before being vacuum freeze-dried (at $-50^{\circ} \mathrm{C}$ ). To characterize fruit quality, the concentrations of total soluble sugars (total SS: glucose, sucrose, fructose), total organic acids (Total OA: citric acid, malic acid, quinic acid) and vitamin C - reduced ascorbate and total vitamin C (dehydroascorbate + reduced ascorbate) - were assayed. Chemical analyses of total SS and total OA were performed using HPLC according to Gomez et al. ${ }^{21}$ Total and reduced vitamin C (total and reduced AsA) were assayed as previously described. ${ }^{15}$

\section{Statistical analysis}

Statistical analyses were done using SAS software. ${ }^{22}$ Mean values were compared using a one-way ANOVA, and differences were determined using the least square mean differences. A significant level was set at alpha $=0.05$.

\section{RESULTS}

\section{Development of reproductive traits under ozone stress}

At the time of ozone exposure, the fourth truss was flowering, and fruits from the second truss had begun setting fruit (Fig. 1). No significant difference occurred in terms of the phytomer emergence (vegetative or reproductive phytomer), and hence on the emergence of the successive trusses (Fig. 1). A significant decrease in 


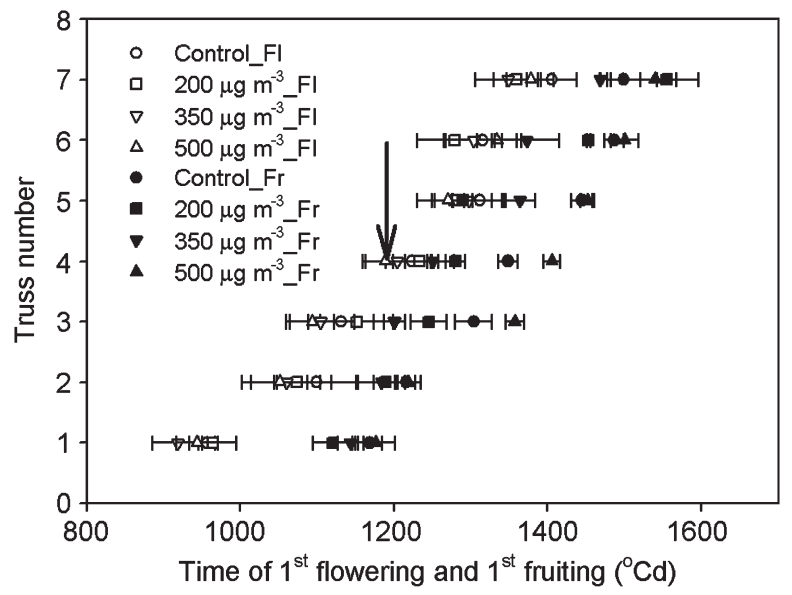

Figure 1. Comparison of time of first flowering $\left({ }^{\circ} \mathrm{Cd}\right)$ and first fruiting $\left({ }^{\circ} \mathrm{Cd}\right)$ in accordance with truss number among the treatments. Open symbols are flowers (FI) and closed symbols are fruits (Fr). Arrow indicates time of ozone application.

flowers per truss $(P<0.02)$ as well as flowers per plant $(P<0.04)$ was observed after ozone exposure at both 350 and $500 \mu \mathrm{g} \mathrm{m}^{-3}$ in comparison with the control (Table 1). From truss numbers 4 to 8 , the number of flowers was reduced by $7-18 \%$ per truss in ozone-treated plants compared to the control. Under ozone stress, the fruit-setting ratio ranged from $77 \%$ to $81 \%$, which was not significantly different from the control plants (79\%) (Table 1).

\section{Yield components and fruit quality traits}

Ozone significantly reduced the numbers of well-developed fruits $(P<0.001)$, indicating that some fruits remained small. Only $29.1-44.7 \%$ of fruits developed into larger sizes in ozone-stressed plants from truss numbers 4 to 8 (Table 1). Comparison of the final size of mature fruits in each truss indicated that the significant reduction of developed fruit number started from truss number 4 and was still significant up to truss number 8 in response to $500 \mu \mathrm{g} \mathrm{m}^{-3}$ ozone. Significant reduction of developed fruit number was still observed in both the 350 and $200 \mu^{-3} \mathrm{~m}^{-3}$ ozone treatments from truss numbers 5 to 8 , except that truss number
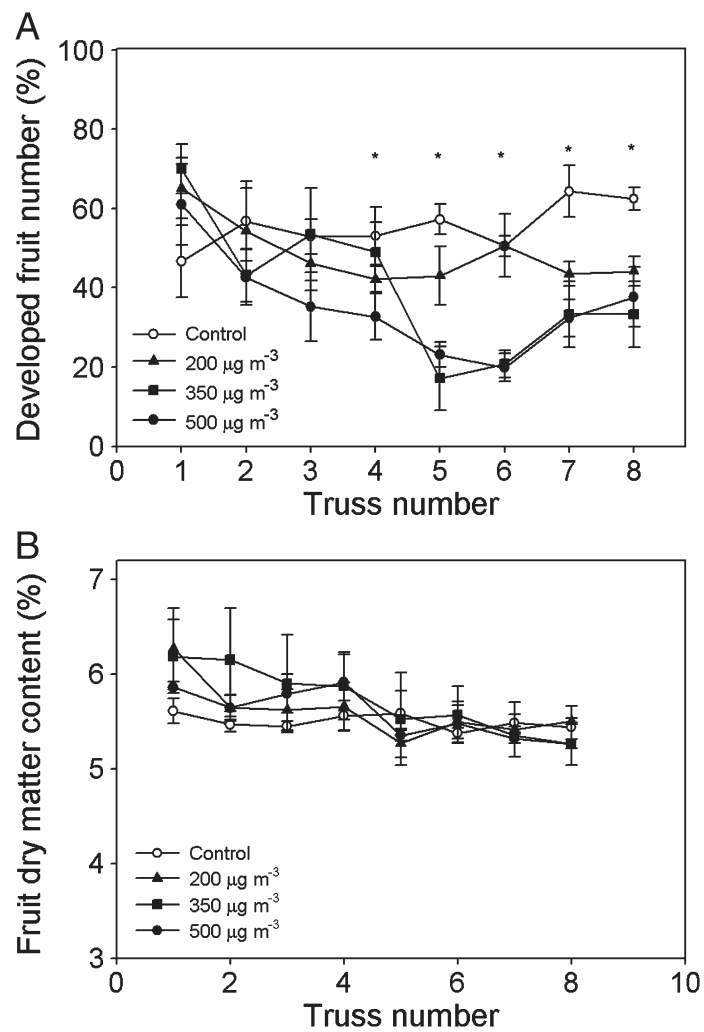

Figure 2. Comparison of percentage of developed fruit number $(A)$ and fruit dry matter $(B)$ in accordance with truss number among the treatments. Asterisks mean significant difference of the treatments in comparison with control.

6 did not show significant reduction of developed fruit number in $200 \mu \mathrm{g} \mathrm{m}^{-3}$ ozone (Fig. 2A). When the ozone treatment was applied, the 8th truss was not yet flowering, but its impact on the developed fruit number was still occurring. The decrease in developed fruit number was larger at the highest ozone concentration. From truss numbers 4 to 8 , ozone at $500 \mu^{-3} \mathrm{~m}^{-3}$ reduced the average number of well-developed fruits by $(-48 \%)$, followed by $350 \mu \mathrm{g} \mathrm{m}^{-3}(-45 \%)$ and $200 \mu \mathrm{g} \mathrm{m}^{-3}(-20 \%)$ (Table 1).

Table 1. Comparison of yield component characters between ozone treated and non-treated plants

\begin{tabular}{|c|c|c|c|c|c|c|c|c|c|c|}
\hline & \multirow{2}{*}{$\begin{array}{c}\text { Total number } \\
\text { of trusses } \\
\text { per plant }\end{array}$} & \multicolumn{2}{|c|}{ Flowers per truss } & \multicolumn{2}{|c|}{ Flowers per plant } & \multirow[b]{2}{*}{$\begin{array}{l}\text { Fruit setting } \\
\text { ratio (\%) }\end{array}$} & \multirow[b]{2}{*}{$\begin{array}{c}\text { Mean fruit } \\
\text { fresh weight }(\mathrm{g})\end{array}$} & \multirow[b]{2}{*}{$\begin{array}{c}\text { Mean fruit } \\
\text { dry weight (g) }\end{array}$} & \multirow[b]{2}{*}{$\begin{array}{c}\text { Developed } \\
\text { fruit number (\%) }\end{array}$} & \multirow[b]{2}{*}{$\begin{array}{c}\text { Total fruit } \\
\text { yield (g) }\end{array}$} \\
\hline & & Before & After & Before & After & & & & & \\
\hline Control & $8.5 a$ & $7.1 \mathrm{a}$ & $8.4 b$ & $21.8 \mathrm{a}$ & $43.8 \mathrm{~b}$ & 79.3a & $40.1 \mathrm{a}$ & $2.2 \mathrm{a}$ & $55.6 c$ & $374.32 \mathrm{a}$ \\
\hline $200 \mu \mathrm{g} \mathrm{m}^{-3}$ & $8.6 a$ & $7.4 a$ & 7.9ab & $24.6 a$ & $40.2 a b$ & $80.5 a$ & $43.8 \mathrm{a}$ & $2.3 a$ & $\begin{array}{l}44.7 b \\
(-20)\end{array}$ & $\begin{array}{l}334.1 a \\
(-10 \%)\end{array}$ \\
\hline $350 \mu \mathrm{g} \mathrm{m}^{-3}$ & $8.5 a$ & $6.9 a$ & $7.3 \mathrm{a}$ & $23.0 a$ & $36.8 a$ & $77.8 \mathrm{a}$ & $43.4 a$ & $2.2 \mathrm{a}$ & $\begin{array}{l}30.7 a \\
(-45)\end{array}$ & $\begin{array}{l}309.4 a \\
(-17 \%)\end{array}$ \\
\hline $500 \mu \mathrm{g} \mathrm{m}^{-3}$ & $8.4 a$ & $7.0 \mathrm{a}$ & $6.9 a$ & $23.2 \mathrm{a}$ & $36.6 a$ & $77.2 \mathrm{a}$ & $42.7 a$ & $2.3 a$ & $\begin{array}{l}29.1 a \\
(-48)\end{array}$ & $\begin{array}{l}291.78 a \\
(-22 \%)\end{array}$ \\
\hline CV (\%) & 19.1 & 15.5 & 10.7 & 17.5 & 11.6 & 10.3 & 34.1 & 27.1 & 15.5 & 25.3 \\
\hline
\end{tabular}



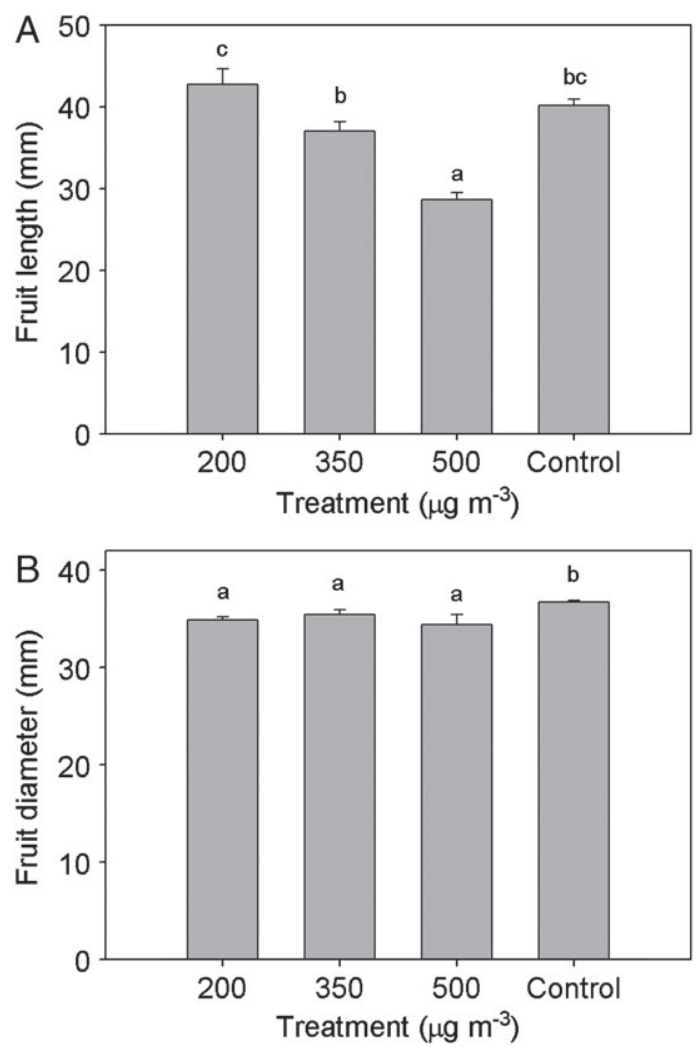

Figure 3. Comparison of fruit length (A) and fruit diameter (B) between ozone treatments and control.

At harvest, mean fruit fresh weight and mean fruit dry matter content in ozone treatments was not significantly different than those of control fruit (Fig. 2B). Ozone-treated plants had fruit yields that were not significantly different from control plants (Table 1). However, fruit length and fruit diameter in ozone-treated plants, mainly at $500 \mu \mathrm{g} \mathrm{m}^{-3}$, were significantly lower than fruits harvested from control plants (Fig. 3), indicating that ozone stress tends to reduce tomato fruit size. These data revealed that a short duration of ozone exposure has little impact on tomato fruit fresh and dry weight and fruit yield, despite a significant impact on number of flowers, well-developed fruit number and fruit size at harvest (Figs 2 and 3 and Table 1).

\section{Determination of fruit quality characteristics}

Fruit quality characteristics here refer to the chemical composition of fruits. Total soluble sugar (SS) content was significantly higher $(P<0.02)$ in the fruits of ozone-treated plants than those of the control plants (Fig. 4A). Glucose content was enhanced up to $11 \%$ by $\mathrm{O}_{3}$ fumigation; however, there was no significant difference in fructose. In contrast, sucrose content was reduced up to $31 \%$ by ozone treatment (Table 2). Among the sugar constituents, reducing sugars (glucose and fructose) represent $97-98 \%$ of SS and are the main contributors to the sweetness of tomato fruits, whereas sucrose represents only $2-3 \%$ of total SS.

An increase in total organic acid (OA) was observed for all ozone concentrations in comparison to the control (Fig. 4B). These differences were mostly due to increased content in quinic acid (+10\%) and malic acid (+24\%) (Table 2). Citric acid and quinic acid were the major organic acids in the fruits, whereas malic acid was less abundant. These changes in fruit composition triggered a significant reduction in sugar:acid ratio after application of $500 \mu \mathrm{g} \mathrm{m}^{-3}$
A
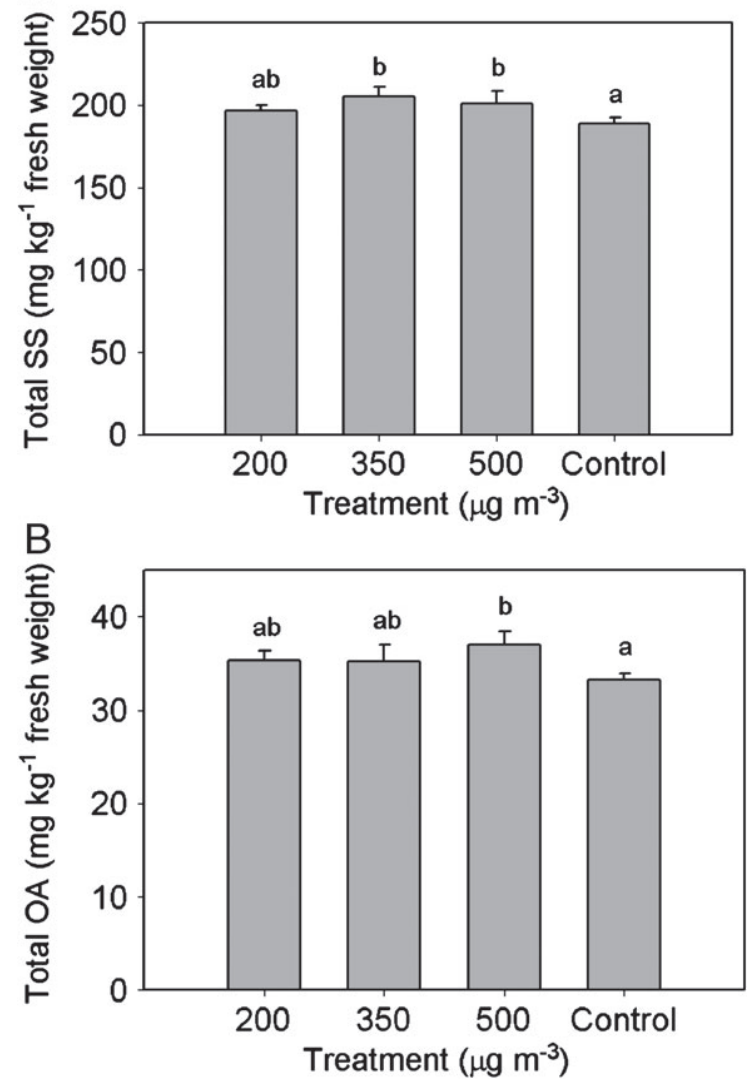

Figure 4. Comparison of total soluble solid (total SS) (A) and total organic acid (total OA) (B) between ozone-treated and non-treated plants.

ozone. The decrease in sugar:acid ratio as the ozone concentrations increased was observed under ozone stress situations (Fig. 5).

With regard to ascorbic acid content (AsA), both total AsA and reduced AsA content of fruits from ozone-treated plants were significantly higher than those of the control $(P<0.005)$, and this was observed even for the lowest ozone treatment. Total vitamin $C$ content increased by up to $19 \%$ and reduced ascorbate up to $18 \%$ in comparison with the control (Table 2).

\section{DISCUSSION}

This research was undertaken to assess the impact of acute ozone exposure on reproductive traits, yield components and fruit quality of tomato. There was a significant decrease in flower number after ozone exposure. Other yield component traits (fruit setting, mean fruit fresh and dry weight, and fruit yield) were slightly or not significantly altered in the present experiment. These slight and not significant ozone impacts might be related to the short-term ozone exposure. Indeed, Drogoudi and Ashmore ${ }^{23}$ reported that ozone exposure $\left(184 \mu^{-3} \mathrm{~m}^{-3}\right)$ for 69 days reduced inflorescence number and inhibited fruit set in strawberry.

Our results showed that a short-term ozone exposure inhibited the correct development of fruits from the flowers or of young fruits that were present at the time of ozone application. Ozone concentration of $200 \mathrm{\mu g} \mathrm{m}^{-3}$ and above significantly reduced the number of well-developed fruits. Gerosa et al. ${ }^{24}$ also stated that chronic ozone exposure of tomato (cv. Oxheart) for 3.5 months gave a significant decrease in both total and marketable fruit number $(-35.7 \%$ and $-30.6 \%$, respectively), whereas fruit size 
Table 2. Comparison of fruit chemical constituents between ozone-treated and non-treated plants

\begin{tabular}{|c|c|c|c|c|c|c|c|c|}
\hline & \multicolumn{3}{|c|}{$\begin{array}{l}\text { Total soluble sugar (SS) } \\
\text { ( } \mathrm{g} \mathrm{kg}^{-1} \text { fresh weight) }\end{array}$} & \multicolumn{3}{|c|}{$\begin{array}{l}\text { Total organic acid (OA) } \\
\text { ( } \mathrm{kg}^{-1} \text { fresh weight) }\end{array}$} & \multicolumn{2}{|c|}{$\begin{array}{l}\text { Total ascorbic acid } \\
\left.\text { ( } \mathrm{g} \mathrm{kg}^{-1} \text { fresh weight }\right)\end{array}$} \\
\hline & Glucose & Fructose & Sucrose & Citric & Malic & Quinic & Total AsA & Reduced AsA \\
\hline Control & $8.03 a$ & $10.73 a$ & $0.49 \mathrm{~b}$ & $1.58 a$ & $0.44 a$ & $1.31 \mathrm{a}$ & $14.36 a$ & $13.74 a$ \\
\hline $200 \mathrm{\mu g} \mathrm{m}^{-3}$ & $8.74 b$ & $10.51 a$ & $0.42 \mathrm{ab}$ & $1.68 \mathrm{a}$ & $0.44 a$ & $1.41 \mathrm{ab}$ & $16.57 b$ & $16.27 b$ \\
\hline $350 \mu \mathrm{g} \mathrm{m}^{-3}$ & $8.93 b$ & $11.24 \mathrm{a}$ & $0.34 a$ & $1.64 a$ & $0.45 a$ & $1.44 \mathrm{~b}$ & $17.03 b$ & $16.28 b$ \\
\hline $500 \mu \mathrm{g} \mathrm{m}^{-3}$ & $8.93 b$ & $10.81 a$ & $0.37 a b$ & $1.77 a$ & $0.54 b$ & $1.41 \mathrm{ab}$ & $16.38 b$ & $15.80 \mathrm{~b}$ \\
\hline CV (\%) & 7.6 & 6.9 & 34.1 & 15.7 & 21.8 & 9.3 & 13 & 13 \\
\hline
\end{tabular}

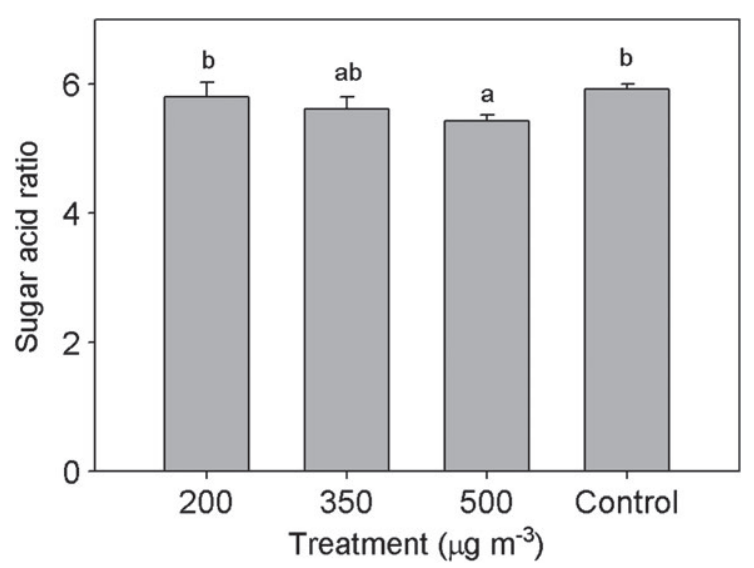

Figure 5. Comparison of sugar:acid ratio between ozone-treated and non-treated plants.

and weight were not significantly reduced. Similarly, Leisner and Ainsworth ${ }^{4}$ reported that ozone did not significantly alter the inflorescence number, flower weight or flower number of several plant species despite a significant reduction in fruit number and fruit weight, which revealed that ozone exposure has less effect on floral initiation and fruit setting than on fruit production. This reduced fruit number could result from the reduced assimilation process.

Ozone has been shown to trigger foliar leaf injury, reduced photosynthetic rate and impaired photosynthetic systems. ${ }^{25,26}$ Reduced root growth and extension rate were also reported by Thwe et al., ${ }^{27}$ as a consequence of leaf injury and dysfunction of photosynthetic systems under ozone stress. ${ }^{28}$ Hence these impacts could lead to decreased availability of energy and resource (carbohydrates and water), which may become limiting for fruit setting ${ }^{29}$ and to sustain organ growth, thus triggering a decrease in the number of well-developed fruits. Consequently, as ozone decreases fruit load, it affects source/sink ratio, which was reported to affect fruit composition and fruit dry matter content. ${ }^{30}$

The results presented here are in agreement with the data reported by Leisner and Ainsworth ${ }^{4}$ that ozone can have direct effects on plant reproductive organs through an effect on carbon assimilation and allocation within the plant. Ozone taken up by the leaves and other photosynthetic tissue has the potential to affect carbon allocation to seeds and fruits leading to possible consequences on yield. In our experiment, the 51-day-old plants had already produced some trusses and small fruits at the time of ozone exposure. Thus a slight decrease of flowers per truss could result from direct impact of ozone exposure and/or indirect impact due to altered carbon acquisition and allocation within the plant. First, the fruit setting was altered, leading to a decrease in the fruit number per truss. Moreover, a temporary decrease in photosynthesis is observed at the plant scale in response to ozone stress. ${ }^{28}$ Therefore the source/sink ratio had been possibly impacted by ozone in the present experiment. Furthermore, a possible shift in the allocation pattern could be observed.

Ozone stress has been shown to decrease photosynthesis as a result of leaf injury and senescence, followed by negative impacts for plant growth and development. ${ }^{2,31}$ Grantz and Yang ${ }^{3}$ indicated that $\mathrm{O}_{3}$ induces an allometric shift in carbohydrate allocation of Pima cotton (Gossypium barbadense L.) due to direct effects on phloem loading.

However, the fact that there were no significant differences in single fruit weight and total fruit yield at the end of the experiment suggests that there was a compensatory mechanism in the reproductive structures. Stewart et $a l^{32}$ also described that a single exposure of ozone induced significant losses of reproductive sites of Brassica napus; however, there were no significant differences in reproductive parameters (seed number per plant, mean seed weight and total seed weight per plant) at maturity. Likewise, seed yield per plant of Brassica campestris was unaffected by ozone exposure during the vegetative phase, despite adverse effects on physiological, vegetative and reproductive processes. These observations indicate that indeterminate species such as $B$. napus and B. campestris possess sufficient compensatory flexibility to avoid reductions in seed production. ${ }^{33}$

With regard to fruit chemical composition, both total SS and total OA content in fruits harvested from ozone-treated plants were significantly higher than those of control fruits. Salles et al. ${ }^{34}$ indicated that the organoleptic quality of tomato fruit is linked to the combination of sugars and organic acids, which determine the sweetness and sour taste, respectively, and thus their concentration levels can significantly affect flavour acceptability by consumers. Thus fruits from ozone-treated plants may be tasty due to higher contents of both sugar and acid. A possible explanation for the increased content in sugars and acids lies in the variation of fruit load between ozone-treated and non-treated plants. It is well known that low fruit load increases tomato fruit sugar content and improves tomato fruit quality. ${ }^{35,36}$ Thus the reduced number of well-developed fruit observed in the ozone-treated plants likely had an indirect effect that influenced the tomato fruit quality.

Tenga et al. ${ }^{37}$ also observed some variation in fruit quality with ozone concentration. Under ozone stress situations, titratable acidity of tomato fruits declined at first and then levelled off in 
response to increasing $\mathrm{O}_{3}$ concentration. These authors suggested that these variations could be related to variation in phloem sap composition or modification in the fruit uptake rather than direct oxidation occurring in the fruits, because $\mathrm{O}_{3}$ was not applied directly to the fruits. Ho and Adams ${ }^{38}$ reported that assimilate and nutrient supplies to the developing fruits also account for fruit quality build-up. Guichard et al. ${ }^{39}$ stated that most of the dry matter of the fruits comes from the assimilates photosynthesized in the leaves and then transported to the fruits as sucrose. Then, sucrose and other sugars in the fruits are transformed into organic acids and other compounds. Thus the mechanisms that control the intake of carbon and water in the fruit play an essential role in determining not only the fruit size but also the dry matter concentration of the fruit and therefore its fruit quality.

Concerning fruit nutritional quality, our data suggest that it may improve following ozone exposure. Indeed, we reported higher content of ascorbate and dehydroascorbate under ozone stress, indicating that fruit vitamin $\mathrm{C}$ content was promoted under ozone stress situations. This supports the hypothesis that ozone stress may improve fruit nutritional quality. Previous reports indicate that fruit ascorbic acid concentration in both fruits and leaves is influenced by the environment. ${ }^{40,41}$ Oliveira et al. ${ }^{42}$ reported that stress conditions during plant development caused increased accumulation of soluble solids as sugars and other compounds, contributing to fruit nutritional quality such as vitamin $C$ and phenolic compounds. It is well known that ascorbate is implicated in plant responses to abiotic environmental stresses and regulates the stress response as a result of a complex sequence of biochemical reactions such as activation or suppression of key enzymatic reactions, induction of stress-responsive protein synthesis, and the production of various chemical defence compounds. ${ }^{43}$ Thus higher contents of ascorbic acid in fruits from ozone-treated plants might result from plant responses against oxidative stress induced by ozone, and help the plants to detoxify ozone, as was previously reported in leaves. ${ }^{44}$ Ozone exposure might thus trigger direct effects on fruit composition in response to oxidative stress.

Environmental conditions and source-sink balance within the plant during fruit development determine the fruit quality. ${ }^{45,46}$ Thus it is necessary to understand how fruit quality may be altered by abiotic factors. Génard et al. ${ }^{47}$ proposed to model fruit growth and quality, considering that the fruit is a hierarchically organized organ composed of cells from different tissues and its quality is the result of a complex chain of various biological processes (cell division and growth, respiration and metabolic reactions), involving different exchanges between the fruit and its environment (transpiration, photosynthesis, phloem and xylem fluxes). Thus knowing the impact of ozone and other environmental factors, genetic make-up and the plant growth conditions would make it possible to predict how changes in the abiotic environment will affect fruit development as well as fruit composition.

In conclusion, we reported that acute ozone exposure up to $500 \mu \mathrm{g} \mathrm{m}^{-3}$ did not significantly alter the reproductive traits of tomato; however, it significantly reduced the well-developed fruit number and altered the chemical composition of fruits. It increased fruit contents of glucose and quinic, malic and ascorbic acids and decreased sucrose content, triggering a lower sugar:acid ratio in fruits harvested from ozone-treated plants. Our data suggest that acute ozone exposure up to $500 \mu \mathrm{g} \mathrm{m}^{-3}$ greatly influences tomato fruit quality, with little impact on the flowering and fruit setting rate. The observation that final fruit yield was not significantly reduced highlighted the possibility that there may be compensatory mechanisms when plants are exposed to acute ozone exposure. It would be interesting to further investigate the impact of repeated ozone applications or longer-term ozone exposure to determine if and how the plant may adapt or not to this stressful environment.

\section{ACKNOWLEDGEMENTS}

We would like to thank the scholarship foundation (French Embassy - Thailand International Cooperation Agency - Thailand Research Fund) for financial support. Staff from the Laboratory of Plant Physiology, Department of Horticulture, Kasetsart University, Thailand, and Laboratory of Chemical Analysis, INRA, UR1115, Plantes et Systèmes de culture Horticoles, Avignon, France, are highly acknowledged for their contribution in conducting this research.

\section{REFERENCES}

1 Science Policy Report, 2008. 21st century: future trends, impacts and policy implications. Royal Society, London (2008).

2 Benton J, Fuhrer J, Gimeno BS, Skärby L, Palmer-Brown D, Ball G et al., An international cooperation programme indicates the widespread occurrence of ozone injury on crops. Agric Ecos Environ 78:19-30 (2000).

3 Grantz DA and Yang S, Ozone impacts on allometry and root hydraulic conductance are not mediated by source limitation nor developmental age. J Exp Bot 51:919-927 (2000).

4 Leisner CP and Ainsworth EA, Quantifying the effects of ozone on plant reproductive growth and development. Glob Change Biol 18:606-616 (2012)

5 Black VI, Black CR, Roberts IA and Stewart CA, Impact of ozone on the reproductive development of plants. New Phytol 147:421-447 (2000).

6 Drogoudi PD and Ashmore MR, Does elevated ozone have differing effects in flowering and deblossomed strawberry? New Phytol 147:561 - 569 (2000).

7 Keutgen AJ and Pawelzik E, Influence of pre-harvest ozone exposure on quality of strawberry fruit under simulated retail conditions. Postharvest Biol Tech 49:10-18 (2008).

8 Flores P, Navarro JM, Carvajal M, Cerdá A and Martínez V, Tomato yield and quality as affected by nitrogen source and salinity. Agronomie 23:249-256 (2003).

9 Malundo TMM, Shewfelt RL and Scott JW, Flavor quality of fresh tomato (Lycopersicon esculentum Mill.) as affected by sugar and acid levels. Postharvest Biol Tech 6:103-110 (1995).

10 Byrne DH, Nikolic AN and Burns EE, Variability in sugars, acids, firmness, and color characteristics of 12 peach genotypes. J Am Soc Hortic Sci 116:1004-1006 (1991).

11 Helyes L, Dimény J, Pék Z and Lugasi A, Effect of the variety and growing methods as well as cultivation conditions on the composition of tomato (Lycopersicon lycopersicum (L.) Karsten) fruit, in Proceedings of IVth International Conference on Managing Quality in Chains, Acta Hortic 712. ISHS, Leuven (2006).

12 Pincemail J, Kevers C, Tabart J, Defraigne JO and Dommes J, Cultivars, culture conditions, and harvest time influence phenolic and ascorbic acid contents and antioxidant capacity of strawberry (Fragaria $\times$ ananassa). J Food Sci 77:205-210 (2012).

13 Gautier H, Diakou-Verdin V, Benard C, Reich M, Buret M, Bourgaud F et al., How does tomato quality (sugar, acid, and nutritional quality) vary with primary ripening stage, temperature, and irradiance? J Agric Food Chem 56:1241 - 1250 (2008).

14 Bénard C, Gautier H, Bourgaud F, Grasselly D, Navez B, Caris-Veyrat C et al., Effects of low nitrogen supply on tomato (Solanum lycopersicum) fruit yield and quality with special emphasis on sugars, acids, ascorbate, carotenoids, and phenolic compounds. J Agric Food Chem 57:4112-4123 (2009).

15 Gautier H, Massot C, Stevens R, Serino S and Genard M, Regulation of tomato fruit ascorbate content is more highly dependent on fruit irradiance than leaf irradiance. Ann Bot 103:495-504 (2009).

16 Veit-Köhler U, Krumbein A and Kosegarten $\mathrm{H}$, Effect of different water supply on plant growth and fruit quality of Lycopersicon esculentum. J Plant Nutr Soil Sci 162:583-588 (1999). 
17 Wert TW, Williamson JG, Chaparro JX and Miller EP, The influence of climate on fruit development and quality of four low-chill peach cultivars. Hortscience 44:666-670 (2009).

18 Reiling K and Davison AW, Effects of exposure to ozone at different stages in the development of Plantago major L. on chlorophyll fluorescence and gas exchange. New Phytol 128:509-514 (1994).

19 Leers K, Development of fertilizer recommendations for field vegetables in Dong Anh district. EU 5th framework $\mathrm{INCO}_{2}$ funded research project, contract no. ICA4-CT-2001-10054. PR 32 (2001).

20 Najla S, Vercambre G, Pagès L, Grasselly D, Gautier H and Génard M, Tomato plant architecture as affected by salinity: descriptive analysis and integration in a 3-D simulation model. Botany 87:893-904 (2009).

21 Gomez L, Rubio E and Augé $M, A$ new procedure for extraction and measurement of soluble sugars in ligneous plants. J Sci Food Agric 82:360-369 (2002).

22 SAS Institute, SAS STAT user's guide, version 9.2. SAS Institute, Cary, NC (2007).

23 Drogoudi PD and Ashmore MR, Does elevated ozone have differing effects in flowering and deblossomed strawberry? New Phytol 147:561-569 (2000).

24 Gerosa G, Marzuoli R, Finco A, Ebone A and Tagliaferro F, Ozone effects on fruit productivity and photosynthetic response of two tomato cultivars in relation to stomatal fluxes. Ital J Agron 1:61-70 (2008).

25 Fiscus EL, Booker FL and Burkey KO, Crop responses to ozone: uptake, modes of action, carbon assimilation and partitioning. Plant Cell Environ 28:997-1011 (2005).

26 Guidi L, Tonini M and Soldatini GF, Effects of high light and ozone fumigation on photosynthesis in Phaseolus vulgaris. Plant Physiol Biochem 38:717-725 (2000).

27 Thwe AA, Vercambre G, Gautier H, Pages L, Jourdan C, Gay F et al., Dynamic shoot and root growth at different developmental stages of tomato (Solanum lycopersicum Mill.) under acute ozone stress. SC Hortic 150:317-325 (2013).

28 Thwe AA, Vercambre G, Gautier H, Gay F, Phattaralerphong J and Kasemsap P, Response of photosynthesis and chlorophyll fluorescence to acute ozone stress in tomato (Solanum lycopersicum Mill.). Photosynthetica 52:105-116 (2014).

29 Bertin N, Competition for assimilates and fruit position affect fruit set in indeterminate greenhouse tomato. Ann Bot 75:55-65 (1995).

30 Prudent $M$, Causse M, Génard M, Tripodi P, Grandillo $S$ and Bertin $\mathrm{N}$, Genetic and physiological analysis of tomato fruit weight and composition: influence of carbon availability on QTL detection. J Exp Bot 60:923-937 (2009).

31 Saitanis CJ and Karandinos MG, Effects of ozone on tobacco (Nicotiana tabacum L.) varieties. J Agron Crop Sci 188:51 -58 (2002).

32 Stewart CA, Black VJ, Black CR and Roberts JA, Direct effects of ozone on the reproductive development of Brassica species. J Plant Physiol 148:172-178 (1996).
33 Black VJ, Stewart CA, Roberts JA and Black CR, Ozone affects gas exchange, growth and reproductive development in Brassica campestris (Wisconsin Fast Plants). New Phytol 176:150-163 (2007).

34 Salles C, Nicklaus S and Septier C, Determination and gustatory properties of taste-active compounds in tomato juice. Food Chem 81:395-402 (2003).

35 Bertin N, Guichard S, Leonardi C, Longuenesse JJ, Langlois D and Navez $B$, Seasonal evolution of the quality of fresh glasshouse tomatoes under Mediterranean conditions, as affected by air vapour pressure deficit and plant fruit load. Ann Bot 85:741 -750 (2000).

36 Saglam N and Yazgan A, Effect of fruit number per truss on yield and quality in tomato. Acta Hortic 486:261 - 264 (1999).

37 Tenga AZ, Marie BA and Ormrod DP, Recovery of tomato plants from ozone injury. Hortscience 25:1230-1232 (1990).

$38 \mathrm{Ho} \mathrm{LC}$ and Adams P, Nutrient uptake and distribution in relation to crop quality, in Hydroponics and Transplant Production, Acta Hortic 396. ISHS, Leuven (1995).

39 Guichard S, Bertin N, Leonardi C and Gary C, Tomato fruit quality in relation to water and carbon fluxes. Agronomie 21:385-392 (2001).

40 Dumas $Y$, Dadomo M, Lucca G and Grolier P, A review: effects of environmental factors and agricultural techniques on antioxidant content of tomatoes. J Sci Food Agric 83:369-382 (2003).

41 Bartoli CG, Yu J, Gómez F, Fernández L, Mclntosh L and Foyer $\mathrm{CH}$, Inter-relationships between light and respiration in the control of ascorbic acid synthesis and accumulation in Arabidopsis thaliana leaves. J Exp Bot 57:1621-1631 (2006).

42 Oliveira $A B$, Moura $C F H$, Gomes-Filho E, Marco CA, Urban $L$ and Miranda MRA, The impact of organic farming on quality of tomatoes is associated to increased oxidative stress during fruit development. PLOS ONE 8:e56354 (2013).

43 Khan TA, Mazid M and Mohammad F, A review of ascorbic acid potentialities against oxidative stress induced in plants. J Agrobiol 28:97-111 (2011)

44 Luwe MWF, and Heber $U$, Role of ascorbate in detoxifying ozone in the apoplast of spinach (Spinacia oleracea) leaves. Plant Physiol 101:969-976 (1993).

45 Rosales MA, Cervilla LM, Sánchez-Rodrígues E, Rubio-Wilhelmi MM, Blasco B, Ríos JJ, Soriano T et al., The effect of environmental conditions on nutritional quality of cherry tomato fruits: evaluation of two experimental Mediterranean greenhouses. J Sci Food Agric 91:152-162 (2010).

46 Valantin-Morison M, Vaissiere BE, Gary C and Robin P, Source-sink balance affects reproductive development and fruit quality in cantaloupe melon (Cucumis melo L.). J Hortic Sci Biotech 81:105-117 (2006).

47 Génard M, Bertin N, Borel C, Bussières P, Gautier H, Habib R et al., Towards a virtual fruit focusing on quality: modelling features and potential uses. J Exp Bot 58:917-928 (2007). 